\title{
Recent technologies in selective removal of arsenic in copper ore processing
}

\author{
A. Kobylyanski \\ Postgraduate student, Saint-Petersburg Mining University, Saint-Petersburg, Russian Federation \\ V. Zhukova \\ Master student, Saint-Petersburg Mining University, Saint-Petersburg, Russian Federation \\ V. Grigoreva \\ Student, Saint-Petersburg Mining University, Saint-Petersburg, Russian Federation
}

\author{
A.Ya. Boduen \\ PhD, Associate professor, Saint-Petersburg Mining University, Saint-Petersburg, Russian Federation
}

\begin{abstract}
The changes of raw material's characteristic and challenges of processing copper ores containing high concentration of arsenic and antimony was considered. The analysis of the main methods shows that alkaline sulphide leaching is the most effective way to process off-grade copper concentrates. Leaching of concentrates' samples containing approximately $1,36 \%$ As and $19.2 \% \mathrm{Cu}$ was studied in alkaline sulphide solutions containing sodium hydroxide and sodium sulphide

Experiments were carried out with the assistance of the laboratory base of St. Petersburg mining university's Common Use Centre. Experimental results of concerning the selective removal of arsenic are presented here.
\end{abstract}

Keywords: copper, arsenic, tennantite, enargite, sulphides, sulfosalt, alkaline leaching, ore processing

\section{INTRODUCTION}

For the copper industry it is the time of chances and challenges. The industry and the market have to face these challenges now, for seizing the chances coming its way in the future. The European Copper Institute predicts (the ECI 2017 Annual Report) the growth in copper consumption in the short term, taking into account the development of industries and expansion of the number of copper products applications.

However, one of the serious challenges for mining companies is the increase of the off-grade mineral reserves in the deposits. This situation is common for many companies of the mining industry including copper sector. Statistical database of the International Copper Study Group and the recent researches indicate that producers are exploiting deposits with low valuable components concentration in the ores.

In this situation copper deposits are being developed by mining companies, and valuable component content in the ore is ranging between 0.5 and $0.8 \%$. This problem is further complicated by the fact that the relatively low-grade mineral resources being extracted are often unconventional and contain more than one valuable component. This leads to unavoidable losses of the valuable components in ore concentration processes and conversion into mining and mineral processing waste (Nevskaya et al., 2019) Consequently, the effective processing 
and the utilisation of the raw materials with various quality characteristics became much more important for industrial companies.

In details, the changes in quality characteristic of the raw materials (especially steady decrease of the content of the valuable component in the ores) lead to the drop of the processing indicators of raw materials. The chemical and mineralogical compositions of the processed concentrates get worse. All these factors have influence on the final metallurgical product's cost.

High concentration of impure elements in the ore composition is also the problem for metallurgical companies. There are many orebodies or materials, which have significant value but also contain arsenic, throughout the world. Processing of copper ores (or any other ores) that contain arsenic is challenging. Arsenic is considered to be a human carcinogen with high mobility in aqueous streams, which in time may lead to increased arsenic concentrations in rivers (Oyarzun et al., 2004, 2006) and drinking water.

The presence of arsenic minerals in copper concentrates complicates their treatment by the conventional smelting-converting process. The sulphides and oxides of arsenic are highly volatile. Thus, in the pyrometallurgical treatment of copper concentrates with high arsenic content, there is a high risk of producing arsenic emissions to the atmosphere. Therefore, the smelters impose heavy penalties on copper concentrates that contain more than $0.5 \%$ arsenic (Ruiz M.C. et al., 2015).

Hydrometallurgical methods can be involved in treatment processes of arsenic containing materials, concentrates and ores as well as complex ones containing any number of metals. Industrial experience of these methods is known worldwide, in CIS, China and the United States the methods are employed for the production of antimony.

Despite the prevalence of pyrometallurgical processes, the global copper production by implementing hydrometallurgical approach increases (Fedoseev et al., 2018; Boduen et al., 2019). Amongst current technologies, an alkaline sulphide hydrometallurgical process has been demonstrated successful results in selective dissolution of arsenic and antimony from a copper concentrate containing enargite and tennantite (Prada et al., 2014; Tongamp et al., 2009; Baláž et al., 2006). In this paper, the process undertakes an alkaline sulphide leaching with a concentrated solution for transformation the arsenic sulphides into soluble compounds. The alkaline sulphide system is essentially a mixture of sodium sulphide and sodium hydroxide. It is an exclusive hydrometallurgical system - very selective lixiviant for the alkaline leaching of tin, gold, antimony, arsenic and mercury.

\section{THE ROLE OF ARSENIC IN COPPER ORE PROCESSING}

Copper production from the copper ores (or any ores) that contain arsenic is challenging due to certain factors. The common copper-arsenic bearing minerals in copper ores are enargite $\left(\mathrm{Cu}_{3} \mathrm{AsS}_{4}\right)$ and tennantite $\left(\mathrm{Cu}_{12} \mathrm{As}_{4} \mathrm{~S}_{13}\right)$. It should be noted that enargite and tennantite contain significant amounts of copper: $48.4 \%$ and $51.6 \%$ respectively. Chalcopyrite, which is employed more for copper production, has $34.5 \%$ of copper content. Removal of enargite and tennantite minerals from the concentrate means valuable metal losses, hence production income. Moreover, according to environmental and plant ecological concerns, pyrometallurgical operations will penalise concentrates that contain arsenic over $0.5 \%$ by weight (sometimes less). The presence of arsenic can also increase concentrates' shipping costs, since concentrates are commonly imported/exported overseas (Castro, 2008; Filippou et al., 2007).

Enargite and tennantite are part of the sulfosalt minerals' class. Sulfosalt minerals differ from sulphides in that semimetal elements such as antimony, arsenic or bismuth in sulphides substitute the sulphur positions, but in sulfosalts they substitute for the metal ions and bond with the sulphur.

There is a dearth of industrial experience and literature concerning the selective removal of arsenic from the copper ores during the processing. The up-to-date methods of processing copper-sulphide ores with mixture of sulfosalt minerals encompass a number of technological problems that significantly complicate the production process. In other words, at the stage of 
ore preparation sulfosalt minerals are usually over grinded due to the very thin mutual germinating of the main ore-forming minerals: pyrite, chalcopyrite, and sphalerite and sulfosalt minerals.

Besides the similarity of the flotation properties of the minerals and over crushing of sulfoarsenides, the process of selective flotation is complicated, because of the main copper sulphides combined with tennantite might be easily turned to sludge, and that leads to higher losses of copper with processing tails as well as challenges in obtaining a conditioned copper concentrate.

Methods and experiments carried out by other researches (Prada et al., 2014; Tongamp et al., 2009; Baláž et al., 2006) have shown the results of arsenic extraction up to $97 \%$. These results can be achieved by using the alkaline sulphide process for processing ores containing enargite and tennantite. In the presence of sulphide, arsenic is believed to transform and to form sodium thioarsenate as shown in the Equation 1:

$$
\begin{aligned}
& \mathrm{Cu}_{12} \mathrm{As}_{4} \mathrm{~S}_{13}+6 \mathrm{NaOH}+6 \mathrm{NaOH} \rightarrow 5 \mathrm{Cu}_{2} \mathrm{~S}+2 \mathrm{CuS}+ \\
& 4 \mathrm{Na}_{3} \mathrm{AsS}_{3}+6 \mathrm{H}_{2} \mathrm{O}
\end{aligned}
$$

Studying these methods and achievement the same arsenic extraction results for processing copper-arsenic concentrates and middling products were one of the key of this research work.

\section{MATERIALS AND METHODOLOGY}

\subsection{Sample preparation}

The samples of middling product and copper concentrate were received from the Uchalinskiy mining and processing plant (JSC «Uchalinsky GOK»), which is one of the largest industrial companies of Southern Ural, (production specialisation - zinc and copper concentrates).

The ores of the region demonstrate a decrease in the average content of valuable components (on average 10.0-15.0\%), as well as a constant grow in the content of related elements such as arsenic, antimony, lead, mercury, fluorine. These raw materials are characterised as difficult to process, multicomponent, with unfavourable texture and structural features. Oreforming minerals have similar processing properties (Nikolaeva, E.S. et al., 2019).

The samples of the study were the concentrate and middling product provided by the JSC «Uchalinsky GOK». The chemical analyses results (ICP) of the samples are presented in the Table 1.

The samples of middling product and copper concentrate were prepared in laboratory conditions by coning and quartering followed by splitting through a 10-channel splitter, obtaining 50 gram of leaching samples. A sample with $\mathrm{P}_{80}$ of approximately $50 \mu \mathrm{m}$ was used for kinetic experiments at different temperatures. The particle size distribution for this sample is shown in Figure 1.

\subsection{Apparatus and procedure}

Experiments were carried out batch-wise in a $300 \mathrm{ml}$ glass jacket cell under atmospheric pressure. Temperature was controlled by a thermostated water bath throughout the process.

Table 1. Chemical analysis of the copper concentrate and middling product (basic elements).

\begin{tabular}{lllllllllllll}
\hline & \multicolumn{1}{l}{ Content (wt. \%) } \\
\cline { 2 - 12 } Sample & $\mathrm{Cu}$ & $\mathrm{Pb}$ & $\mathrm{Zn}$ & $\mathrm{Fe}$ & $\mathrm{Co}$ & $\mathrm{SiO}_{2}$ & $\mathrm{Al}_{2} \mathrm{O}_{3}$ & $\mathrm{Cd}$ & $\mathrm{As}$ & $\mathrm{Sb}$ & $\mathrm{Ag}$ \\
\hline Copper concentrate UGOK & 16.0 & 23.8 & 0.8 & 5.3 & 0.1 & 1.94 & 0.82 & 0.03 & 1.36 & 0.21 & 0.009 \\
Middling UGOK & 6.22 & 0.74 & 7.3 & 24.4 & 0.1 & 4.02 & 1.32 & 0.03 & 1.36 & 0.19 & 0.009 \\
\hline
\end{tabular}




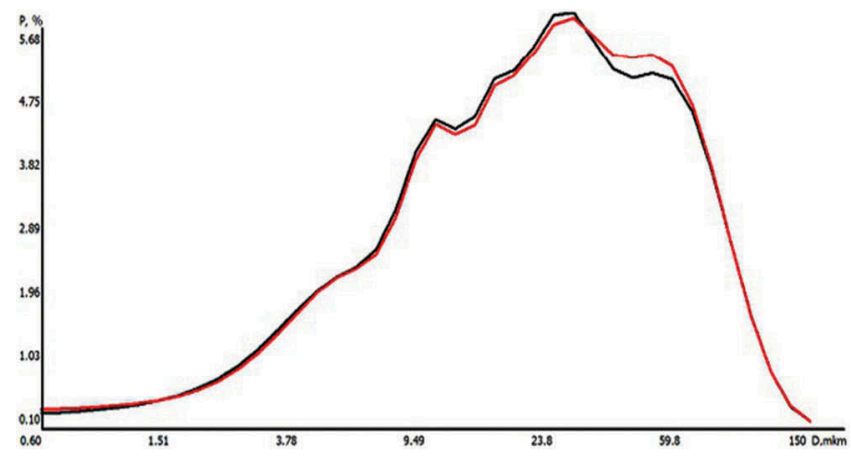

Figure 1. Particle size distribution for the enargite sample used for determination of the rate controlling process, $\mathrm{P} 80=50 \mu \mathrm{m}$.

Agitation was provided by a mechanical paddle agitator during tests. All chemicals were of analytical grade and were used as received. In order to avoid evolution of hydrogen sulphide, leach solutions were prepared separately by dissolving sodium hydroxide in distilled water and dissolving sodium sulphide in distilled water in separate glass cell. Thereafter both solutions were mixed together in the glass jacket cell. It should be noted that all $\mathrm{NaOH}$ concentrations written below also include the $\mathrm{NaOH}$ produced by the hydrolysis of $\mathrm{Na}_{2} \mathrm{~S}$ according to the Equation 2.

$$
\mathrm{Na}_{2} \mathrm{~S}_{(a q)}+\mathrm{H}_{2} \mathrm{O}_{(l)} \leftrightarrow \mathrm{NaOH}_{(a q)}+\mathrm{NaHS}_{(a q)}
$$

The samples for analysing, approximately $10 \mathrm{ml}$ of pulp, were drawn from the leaching reactor periodically (in some test - only in the final stage), filtered and sent for analysis. The remaining pulp that was not used for analysis was immediately returned to the reactor. In this experimental work the studied parameters included concentration of sodium sulphide and sodium hydroxide, temperature, agitation, $\mathrm{P}_{80}$ and pulp density and their effect on the dissolution behaviour of arsenic, antimony, iron and copper.

\section{RESULTS AND DISCUSSION}

During the experimental work certain parameters were determined, studied and described. The effects of temperature and hydroxide concentration are important for the leaching kinetics. In general, Figure 2 shows that there is a clear improvement in the kinetics of arsenic removal as temperature is increased.

The best results were observed when both reagents were taken in high concentrations (4 $\mathrm{M} \mathrm{NaOH}$ and $1.5 \mathrm{M} \mathrm{Na}_{2} \mathrm{~S}$ ) - almost $100 \%$ of arsenic extraction. This strong concentration and temperature dependence is very clear evidence that the controlling mechanism is a chemical reaction taking place on the surface of the particles (Levenspiel, 1999; Petrov, G. et al., 2018).

The decrease of the reagents' concentration declines the leaching rate significantly. Results of experiments 1 and 2 confirm that the concentration of both sodium hydroxide and sulphide has immediate impact on the leaching process (Table 2).

The temperature impact was studied in the range of 85,90 и $95^{\circ} \mathrm{C}$. In this group of experiments other parameters were kept constantly:

- process time -4.5 hours;

- agitation rate $-600 \mathrm{rpm}$;

- reagents concentration $-3,5 \mathrm{M} \mathrm{NaOH}$ и 1,5 $\mathrm{M} \mathrm{Na}_{2} \mathrm{~S}$. 


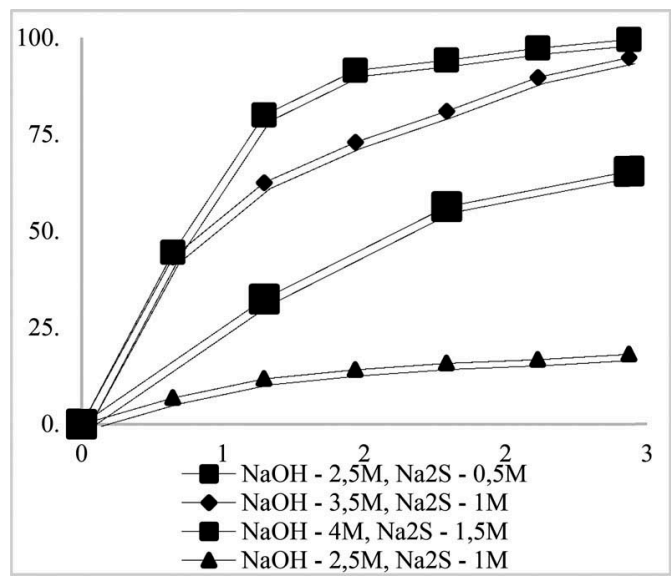

Figure 2. Effect of $\mathrm{NaOH}$ and $\mathrm{Na}_{2} \mathrm{~S}$ on the arsenic extraction at $95^{\circ} \mathrm{C}$ in $250 \mathrm{ml}$ of solution.

Table 2. Parameters and results of experiments - the concentration influence.

\begin{tabular}{lllllll}
\hline & & & \multicolumn{3}{l}{ Concentration } & \\
\cline { 5 - 6 } Experiment & Temperature $\left({ }^{\circ} \mathrm{C}\right)$ & Liquid/solid rate & Time $(\mathrm{h})$ & $\mathrm{NaOH}$ & $\mathrm{Na}_{2} \mathrm{~S}$ & As removal (\%) \\
\hline 1 & 95 & 10 & 3 & 2.5 & 0.5 & 18.10 \\
2 & & & 2.5 & 1.0 & 65.44 \\
3 & & & 3.5 & 1.0 & 92.86 \\
4 & & & 4.0 & 1.5 & 99.56 \\
\hline
\end{tabular}

The results of experiments follow the same trend as previous ones. The highest temperature level provides the best arsenic removal rate (Figure 3; Table 3).

According to the results of experiments' analysis, copper and iron was found in leaching solutions in concentrations $12 \times 10^{-4}(\mathrm{~g} / \mathrm{l})$ and $78 \times 10^{-4}(\mathrm{~g} / \mathrm{l})$ respectively. This trend indicates high selectivity of leaching process.

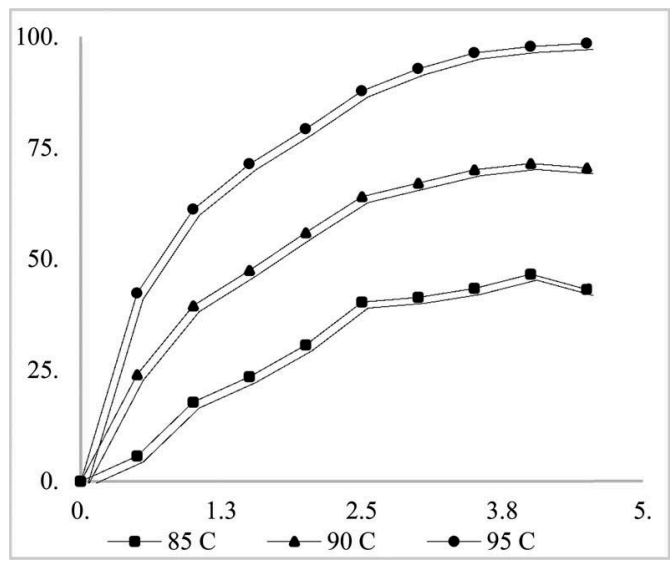

Figure 3. Effect of temperature on the arsenic extraction in $250 \mathrm{ml}$ of solution with concentration 3,5 M $\mathrm{NaOH}$ и $1,5 \mathrm{M} \mathrm{Na}_{2} \mathrm{~S}$. 
Table 3. Parameters and results of experiments of the temperature impact.

\begin{tabular}{lllllll}
\hline & & & \multicolumn{3}{l}{ Concentration } & \\
\cline { 5 - 6 } Experiment & Temperature $\left({ }^{\circ} \mathrm{C}\right)$ & Liquid/solid rate & Time $(\mathrm{h})$ & $\mathrm{NaOH}$ & $\mathrm{Na}_{2} \mathrm{~S}$ & As removal $(\%)$ \\
\hline 1 & 85 & 10 & 4.5 & 3.5 & 1.0 & 43.21 \\
2 & 90 & & & & & 70.54 \\
3 & 95 & & & & 98.57 \\
\hline
\end{tabular}

\section{CONCLUSION}

The existing industrial and scientific experience in technologies of arsenic extraction from copper concentrates and middling products does not provide appropriate solutions for the industry.

The existing methods of flotation cannot separate copper and zinc sulphides from sulfosalt minerals completely, that increases the concentration of arsenic in the product.

Therefore, the smelters impose heavy penalties on copper concentrates that contain more than $0.5 \%$ arsenic. All this factors makes this area of research very relevant.

The alkaline sodium sulphide leaching of copper concentrates and middling products efficiently removes arsenic, and produces a "pure" copper product. Due to this fact the selective leaching of arsenic and antimony using sodium sulphide in the alkaline solutions is a prospective way of upgrading copper-gold-silver concentrates to make them suitable for smelting. This fact creates an opportunity for the mining companies to extend the raw materials base for the production from off-grade mineral reserves.

At the moment, the main direction of modern research in this area is focused on the identification of effective reagent regime and influences of the mechanical activation on the process.

The reported study was funded by RFBR according to the research project 18-29-24103.

\section{REFERENCES}

Anderson, C.G. \& Twidell, L.G. 2008. The alkaline sulphide hydrometallurgical separation, recovery and fixation of tin, arsenic, antimony, mercury and gold. Lead and Zinc 2008: 121-132.

Baláž, P., Achimovičová, M. 2006. Selective leaching of antimony and arsenic from mechanically activated tetrahedrite, jamesonite and enargite. International Journal of Mineral Processing 81: 44-50.

Boduen, A. \& Fokina, S. \& Petrov, G. \& Andreev, Yu. (2019). Ammonia autoclave technology for the processing of low-grade concentrates generated in flotation concentration of cupriferous sandstones. Obogashchenie Rud. 33-38. 10.17580/or.2019.02.06.

Fedoseev, I. V., Barkan, M. S., Kornev, A. V., and Danilov, A. S. (2018). Theoretical Foundations and Technological Capabilities of Hydrocarbonyl Process of Recovering Copper from Technogenic Wastes. Journal of Ecological Engineering, 19(5), pp.33-37.

Filippou, D., St-Germain, P., Grammatikopoulos, T., 2007. Recovery of metal values from copperarsenic minerals and other related resources. Miner. Process. Extr. Metall. Rev. 28 (4): 247-298.

Nadkarni, R.M \& Kusik, C.L. 1988. Hydrometallurgical removal of arsenic from copper concentrates. Arsenic Metallurgy Fundam. Appl. Proc. Symp: 263-286.

Nevskaya, M.A.; Seleznev, S.G.; Masloboev, V.A.; Klyuchnikova, E.M.; Makarov, D.V. Environmental and Business Challenges Presented by Mining and Mineral Processing Waste in the Russian Federation. Minerals 2019, 9, 445.

Nikolaeva, E.S., Talovina, I.V., Nikiforova, V.S., Heide, G. 2019. Chemical composition and genesis of serpentinite group minerals in nickeliferous weathering crust of the Elov deposit (Urals). Scientific and Practical Studies of Raw Material Issues: 3-10.

Oyarzun, R., Guevara, S., Oyarzun, J., Lillo, J., Maturana, H., Higueras, P. 2006. The Ascontaminated Elqui river basin: a long lasting perspective (1975-1995) covering the initiation and development of $\mathrm{Au}-\mathrm{Cu}-\mathrm{As}$ mining in the high Andes of northern Chile. Environ. Geochem. Health 28 (5): 431-443.

Oyarzun, R., Lillo, J., Higueras, P., Oyarzun, J., Maturana, H. 2004. Strong arsenic enrichment in sediments from the Elqui watershed, northern Chile: industrial (gold mining at El Indio-Tambo district) vs. geologic processes. J. Geochem. Explor. 84 (2): 53-64. 
Parada, F., Jeffrey, M.I., Asselin, E. 2014. Leaching kinetics of enargite in alkaline sodium sulphide solutions. Hydrometallurgy 146: 48-58.

Petrov, G. V. \& Fokina, S. B. \& Boduen, A.Y. \& Zotova, I.E. \& Fidarov, B.F. 2018. Arsenic behavior in the autoclave-hydrometallurgical processing of refractory sulfide gold-platinum-bearing products. International Journal of Engineering and Technology (UAE) 7: 35-39.

Tongamp, W., Takasaki,Y. \& Shibayama, A. 2009. Arsenic removal from copper ores and concentrates through alkaline leaching in NaHS media. Hydrometallurgy 98: 213-218. 